DOI: $10.14746 /$ por.2018.2.4

\title{
A WRITER OR A CREATOR OF THE TEXTUAL WORLD: ANTHOLOGY AS A MIRROR OF THE POST-WWII UKRAINIAN LITERATURE
}

\author{
Olena Haleta ${ }^{1}$ \\ (Львівський національний університет імені Івана Франка; \\ Український Католицький Університет)
}

Słowa kluczowe: antologia, pisarz, literatura ukraińska, mit, wspólnota czytania

Keywords: anthology, writer, Ukrainian literature, myth, reader community

\begin{abstract}
Abstrakt: Olena Haleta, PISARZ, CZYLI TWÓRCA ŚWIATA TEKSTOWEGO: ANTOLOGIA JAKO ZWIERCADŁO LITERATURY UKRAIŃSKIEJ PO II WOJNIE ŚWIATOWEJ, „PORÓWNANIA" 2 (23), 2018 T. XXIII, S. 47-62. ISSN 1733-165X. Po II wojnie światowej antologia literacka staje się jednym z najważnejszych sposobów reprezentacji literatury ukraińskiej, który zmienia się w zależności od definiowania i redefiniowania statusu pisarza. Podczas gdy w literaturze radzieckiej pod opieką Akademii Nauk pojawiają się wydania wielotomowe, konstruujące postać pisarza jako uczestnika socjalistycznej reorganizacji rzeczywistości, antologie emigracyjne rozwijają mit o pisarzu jako twórcy świata słów, stającego się nową "przestrzenią spotkania” dla całej wspólnoty kulturowej.Antologie literackie opublikowane po upadku Związku Radzieckiego (których liczba rośnie wielokrotnie) odzwierciedlają wszystkie problemy transformacji tożsamości autorów od wieszcza do gracza w niepewnej rzeczywistości, a także różne modele mitologizacji twórczości od romantyzmu do postmodernizmu. W tym kontekście szczególnie widoczna staje się zmiana natury gatunkowej antologii, która stopniowo przechodzi z kolekcji do projektu. Z jednej strony zauważalny jest efekt komercjalizacji literatury w warunkach rynkowych, przekształcenie pisarza w „producenta” towaru tekstowego. Z drugiej strony, obok klasycznego pisarza, który w uznawany przez czytelników sposób reprezentuje wartości estetyczne, powstaje postać pisarza jako intelektualisty publicznego, podejmującego wyzwanie tworzenia nowych zmysłów i nowych form wypowiedzi na aktualne tematy.
\end{abstract}

Abstract: Olena Haleta, A WRITER OR A CREATOR OF THE TEXTUAL WORLD: ANTHOLOGY AS A MIRROR OF THE POST-WWII UKRAINIAN LITERATURE, "PORÓWNANIA" 2 (23),

1 E-mail: olena_haleta@yahoo.com 
2018 VOL. XXIII, P. 47-62. ISSN 1733-165X. After the II World War, literary anthology has become one of the most important means of representing Ukrainian literature, and it has changed depending on the definition and redefinition of the writer's status. In the meantime, in the Soviet literature under the supervision of the Academy of Sciences, there appear multi-volume editions constructing the figure of the writer as a participant in the socialist reorganization of reality, emigration anthologies develop the myth of the writer as the creator of the textual world, becoming a new "common place" for the entire cultural community. Literary anthologies published after the collapse of the USSR (whose number has grown manyfold) reflect all the problems of transforming the identity of the author from the prophet to the player in an uncertain reality, as well as various models of mythologizing creativity from romanticism to postmodernism. In this context, the change in the genre of anthology becomes especially noticeable; it gradually moves from the collection to the project. On the one hand, commercialization of literature in market conditions and the transformation of the writer into a "producer" of textual goods are visible. On the other hand, next to the classic writer who, in a manner recognized by readers, represents aesthetic values, there emerges the figure of a writer as a public intellectual who undertakes the challenge of creating new meanings and new forms of expression on current issues.

Since the 19th century, anthologies have played an important role in the history of Ukrainian literature and in the general process of the formation of the national cultural community. All while the national literary tradition and canon were being established, Ukrainian literature was deprived of powerful culture-creative mechanisms, in particular the national system of education and periodicals as an essential prerequisite for the development of literary criticism. In the Ukrainian tradition, however, the anthology as an "important niche of the literary sphere" (Pavlyshyn 84) differs in its structure and functions from the textbook or chrestomathy. If this latter is a part of a canon-oriented curriculum, then the anthology serves as a means of rapid reaction to cultural and literary changes, and is not limited by educational needs. While textbooks and readers work on the principle of repetition for the approval of canonical lists of names and works, anthologies present the actual literature in accordance with the understanding of the status and role of the writer. Such representations are implicitly manifested in different compilation strategies reflecting the "author's myths" in various reader communities. Not only classical collections but also those less noticeable at the time of its release often become signals of changes in the collective imagination and cultural formations.

Anthology as a genre: constructing cultural identity. Anthologies remained aside the strong interests of literary theorists for a long time both in Ukraine and abroad. Several researchers addressed this topic no sooner than the 1990s, although first attempts to consider collective editions as a special kind of creativity appeared in writings by the formalists. In 1928 Viktor Shklovsky wrote: "now a journal can exist only as a specific literary form. It should repose not only on the captivation of individual parts, but on the captivation of their connection as well" (Shklovsky 114, 116). In turn, Yury Tynyanov qualified journals as literary phenomena (Tynyanov 1977a, 147) stressing that "journals and almanacs existed in the past, but only now- 
adays they are perceived as peculiar "literary works", "literary facts"" (Tynyanov 1977b, 257).

To analyse "secondary" cultural phenomena Claude Lévi-Strauss proposed the term "bricolage", indicating that elements previously included in other integrities change their function in the newly created whole (Lévi-Strauss 16-22). According to Gerard Genette, terminologically an anthology should be considered as solid "literature in the second degree" whose fragments are not only marked by an individual authorship, but are also linked by contextual (the order of text fragments in an anthology), architextual (intra-genre), metatextual (expressed through prefaces, postfaces, biographic sketches, interpretations and self-interpretations) connections (see Genette). Based on the metonymic principle, such a fragmentary text refers a reader to a certain whole featured by the literature of its part.

On the other hand, nowadays the concept of a collection becomes the most effective theoretical tool used to analyse literary anthologies. It has a long history dating back to the works of the 19th century authors (Honore de Balzac (Sánchez, 177), Johann Wolfgang von Goethe (Sánchez, 257; Iampolski, 90-91; see also Goethe; Schellenberg)). Subsequently, the concept had been developed and established by Walter Benjamin (see Benjamin), Jean Baudrillard (Baudrillard, 85-106), Werner Muensterbergers (see Muensterbergers), Krzysztof Pomian (see Pomian 1996a, 1996b), Susan Stewart (see Stewart), Susan Pearce (see Pearce), Boris Groys (see Groys, 1997a, 1997b), Paul van der Grijp (see Grijp), John Elsner and Roger Cardinal (see Elsner and Cardinal), and Yvette Sánchez (see Sánchez) until it turned into one of the key cultural concepts in James Clifford's works (Clifford, 203-271). Each collection falls in line with a certain plot and envisages the perception, i.e. the ability to comprehend and evaluate, classify and contextualize. Factuality is obvious, though it is not the only one and hardly the formal feature of such collections. Their value depends not only on the completeness but on the way this or that phenomenon is represented, their potential to respond to new inquiries of the receptive community and the persuasiveness in creating new and complex narratives about its own cultural identity.

Aleida Assmann was the first who applied the idea of collecting to literature. She considered the shift from a text to a collection as a sign indicating the transition from structuralism to literary anthropology (Assmann, Gomille, Rippl 7-20). Finally, researchers such as Helga Essmann (see Essmann), William Germano (see Germano), Barbara Korte (see Korte), Jeffrey R. Di Leo (see Di Leo), Anne Ferry (see Ferry), Barbara Benedict (see Benedict) and Anders Olsson (see Olsson) focus their attention on the anthologies as a kind of a collection which not only reflects but sorts literature and serves as a means of both a compiler's creative expression and a creation of a collective cultural identity. Anthology as a literary form opens new perspectives for research and formulates new inquiries; it not only reflects the past but forms the ways of interpreting the present and vision of the future. The German 
researcher, Henrike Schmidt, calls the anthology a performative and intertextual genre that provides self-understanding of literature; in other words, a genre that tells and explains readers what literature is in general and what the uniqueness of each national literature is in particular (see Schmidt). An anthology becomes a literary project which involves restructuring of the initial material and a certain policy in its processing. The policy is expressed through a specific hierarchy of values, selection, definition of the field and rules of the game itself, as well as rules for its valuation (see Haleta 59-118).

Ukrainian modern tradition: from the integrity of literature to the diversity of authors. If the classical approach considers an anthology as a mechanism for establishing a literary canon, that is, the selection and hierarchisation of available authors and works, the broader understanding of the genre as a mechanism for generating images of literature allows us to suggests that anthologies also define the reader's ideas about the borders of literature and the nature/status of the authorship itself. By using the first Ukrainian anthologies as an example, it is possible to observe interesting attempts to reconcile the idea of the integrity of literature and the idea of the uniqueness of a writer, and in general to determine the role of individual authors in the formation of literature. In the first proto-anthological publication of the new Ukrainian literature, "Lastovka: Works in Little Russian Language" (1841) edited by Yevhen Hrebinka (see Hrebinka) the collective and author's works are not separated. Along with multi-genre authored texts here are "some Little Russian folk songs, proverbs, sayings, poems and fairy tales".

In the first anthology of modern Ukrainian literature entitled "Rus' Antology" (1881) there are no authored selections (see Antolohia ruska). The poems by the same author are scattered over the publication, the author's name is given only below but not before the corresponding texts. Accordingly, the works are presented achronologically according to the compiler's design (furthermore, the compiler's name is not specified in the publication). Only on the content page works are grouped per the authors names, the list of which is given in the alphabetical order (in the list we can see that Shevchenko's works are placed on the 1st, 16th, 36th, 49th, 56th, 66th, 99th, 110th, 133rd, 157th and 167th pages).

Both publications are ruled by the idea of representing a certain whole, i.e. national literature, differenciated from other national literatures. Changes in the structure of sequent anthologies appearing at the turn of the 19th and 20th centuries, such as "Age" (see Domanytskyi, Yefremov) and "Ukrainian Muse" (see Kovalenko), and the emergence of authored collections indicate an importance of individual creativity. The number of writers represented in each publication gradually increased. But the newest collections such as "Chords" by Ivan Franko (1903) asserted a new generations and artistic styles (see Franko) separated from classical tradition. Despite the fact that such striking structural changes are not practically registered in subsequent publications, they offer several different models determining the status 
and role of a writer in literary cultures formed under various circumstances during the 20th -21st centuries.

The first half of the 20th century in Ukrainian literature is marked by the desire to represent the tradition and form the canon, emphasizing the continuity of literature over time and unity in space (it revolves around the Ukrainian-language legacy within several states). The WWII and its consequences (change of state borders, post-war emigration and the formation of the diaspora), subsequent political processes and intellectual proposals substantially altered modes of the genre existence. Numerous publications appearing during several decades indicate the changes which occured in the literary myth, i.e. conscious and subconscious representations about a writer and his relationship to the text, literature and reader.

Soviet institutionalization: author as a character. In practice, the first Soviet anthologies of Ukrainian literature appeared after the WWII. The anthological projects of the early 1930s published in Kyiv and Kharkiv can hardly be recognized as Soviet (in the ideological sense): the compilers of these publications still cherished the idea of the unity of national literature (see Yakubskyi; Atamaniuk, Pluzhnyk, Yakubovskyi) but they perished during the time of repressions in the mid-1930s. In the late 1930s, it began the centralized preparation of ideologically verified textbooks and chrestomathies by the Institute of Literature (a subdivision of the Academy of Sciences of the Ukrainian SSR). The above projects were completed after the WWII. The next step was the preparation of academic anthologies - first of all the Ukrainian Soviet one (see Adelheim), and then the pre-Soviet (pre-October) literature (see Rylskyi and Nahnybida). Polish scholars, Wojciech Tomasik and Jerzy Smulski, even argue that collective publications, like anthologies and almanacs, "became the most common representation of socialist realism" not least because of the "collective nature of the publications, intrinsic to the Stalinist culture" (Łapiński, Tomasik, 14).

Anthologies of the 1950s were published at central state publishing houses; their content was strictly supervised by editorial boards. It so happened that prefaces were written not by editors but by people responsible for ideological and literary features of a common project. For example, the 3rd and 4th volumes of "Anthology of Ukrainian Poetry" (1958) edited by Mykola Nahnybida start with the preface by Leonid Novychenko. It is worth to note that the authors whose works are included in the publication are often criticized. And this is not a single case, but a cross-cutting strategy. First of all, the author of the preface points to the exemplarity of Russian literature which was the first "to embody the historical turning point in the life of mankind signalled by the Great October Socialist Revolution" (Rylskyi, Nahnybida, v. 3, 9). All other literatures are assigned the role of imitators, disciples and apprentices.

With several exceptions, the author of a preface highlights not only to the visible or imagined achievements (from the socialist realism perspective) of poets, but also 
rebukes them for their drawbacks, naturally, ideological ones as well. Volodymyr Sosiura, Yurii Yanovskyi, Yevhen Pluzhnyk, Mykhail Semenko, Geo Shkurupii, Valerian Polischuk, even the academician of the Academy of Sciences of the Ukrainian SSR Maxym Rylskyi, who was entrusted to edit the first two volumes of the above publication and to write its preface, were not kept away from criticism. Novychenko bespatters all of them with stylistic quests, deviations, experiments, although at the end he mentions the ideological conversion. The value of poetry is thus measured per the ideological scale, the instance of the authorities stands outside the literary limits, and no one can feel sufficiently certain about his place in the approved canon. It would seem that academic anthologies with their powerful mechanism of canonization is not the place for critical accusations against contemporary poets. However, such strategy of marking key figures as "not fairly good" singers of the Soviet reality and reminding their former drawbacks makes them dependent on the autocratic centre, leaving room for the exclusively ideal writer, "the writer Stalin" in Mikhail Weiskopf's wording (see Weiskopf). All the rest are only characters of the total archive stuff, whose biographies are built per recognizable models. Actually, each poetic collection is preceded with a short biography created according to the recognizable model. In particular, it emphasizes the worker's or peasant's origins of an author and his revolutionary activity. Besides published works, the membership in the Communist Party and involvement in the process of "communism construction" are mentioned. The post-Stalin era rehabilitation is censored; for those who were shot dead during the 1930s repression it is indicated that the author died in 1937. It can be said that all biographical profiles are written according to one scenario. In every event, they tell the Soviet versions of becoming a "new man". The number of represented authors increases from volume to volume (34 - 38 - 42 59) whilst the personal collections of works decrease to 2-3 poems. Consequently, the Soviet modernity appears rather in characters than in personalities since their typified biographies turn into a numerously repeated story of a "Soviet man". The anthologies themselves canonize not so much authors as the method of socialist realism itself subordinated to the ideological project of educating a new communist era man personality (see more detailed in Haleta 207-228).

Anti-Soviet alternative: author as a victim and a hero. Publications created by the post-war emigrants appeared synchronically to the Soviet anthologies. They were aimed to somehow represent the alternative version of the Ukrainian literary tradition and the then-time. The recently repressed, destroyed and silenced past becomes a place of competition. Appealing to the genre of canonical nature such anthologies use the "power of the list" seeking to create the complete list of victims of the Soviet regime, as it is seen in the "Broken Strings: Anthology of Poetry of the Fallen, Shot, Tortured and Exiled in 1920-1945" published in 1955 (see Kravtsiv). The martyrology-themed publications turned into specific gestures-accusations, focusing cultural imagination on a violent death as a biographical anchor of 
authors belonging to the previous generation. From the compiler's and the entire reader community's perspective they perform the function of a memory-debt, i.e. they bring back the traumatic past, which at the same time appears to be the period of the highest literary development and greatest loss. The aesthetic principle yields to the ethical one: authors-victims receive their voice while scarifying their life. Emphasizing the irreplaceable loss, such publications also represent the lost future - not only the repressed literature but also the one that could potentially develop under more favourable conditions. Anthologies recalling forced literary loss are still being published. The most typical example is "Crucified Muse: Anthology of the Ukrainian Poets Who Died a Violent Death" published by Yuri Vynnychuk in 2011 (see Vynnychuk), where some authors are represented only with biographical silhouettes based on fragmented evidence since no literary works were preserved.

Finally, a crime evidenced by martyrology-themed anthologies is primarily a crime against the whole literature. For the first time, this idea was clearly articulated in the publication "Executed Renaissance: Anthology from 1917 to 1933: Poetry - Prose - Drama - Essay" published by Yuri Lavrinenko in 1959 (see Lavrinenko). Inspired by Jerzy Giedroyc's idea, Lavrinenko reduced the number of authors as compared to the previous projects. Instead, he included in his collection the works of writers who had managed to survive repressions. However, the ideological pressure significantly influenced them and this led to the loss of poetic individuality. In Lavrinenko's anthology, the national literature becomes a victim and authors are selected based on their contribution into the creation of its new quality, i.e. Neo-Baroque, or "clarinetism". Despite lengthy biographical silhouettes, authors are portrayed not only as biographies, but also as cultural figures who, regardless of the circumstances, create a new literary quality. Unlike broken lives, the broken tradition can be picked up and developed. For this very reason, "Executed Renaissance" anthology offers a life-affirming programme along with the information on the tragedy. According to the editor, the above programme rests on the legacy by Ukrainian writers of the 1920's and 1930's. Therefore, the responsibility to ensure that their sacrifice, not tragic, but heroic one, was not useless falls on the readership.

Right to language: author as a demiurge. Such a situation was later repeated in post-Soviet Ukraine; however, it is marked with an internal contradiction: a responsibility imposes some restrictions, while literature, especially modern, develops through overcoming such restrictions. The cultural heritage claimed by the post-traumatic generation is the language itself - the only area within which an identity is built up in an ectogenic (emigration) or alienated (totalitarian) space. The two-volume book "Coordinates: Anthology of Ukrainian Poetry in the West" edited by Bohdan Boychuk and Bohdan Rubchak (1969) included the works of 68 authors and became a deliberate attempt to create a new cultural space open to searches and experiments (see Boychuk and Rubchak). The new cultural community did not consider itself to be a community of exiles any longer, rather the generation of indi- 
vidualists-travelers for whom the relocation became a way of existence and a condition enabling their creativity. They cognise their creativity as self-sufficient and self-worth as re-focused from the past on the modernity, namely, on the poetics of modernism.

Even in a more pronounced manner the above policy was manifested in the anthology "Beyond the Tradition" edited by Bohdan Boychuk (1998). Not the adherence to the tradition Boychuk considers as the driving mechanism of literature but the ability to self-uptake the effects of a new environment and to embody them in the individual creativity. He recognizes the language as the only framework uniting men of literature with their predecessors, not the subject, and, especially, not the ideological content of literature. It is worth to note that the editor does not speak about the aesthetic perfection of works, but about their otherness as a criterion to be selected for an anthology. This way he once again justifies the relevance of the modernist trend in Ukrainian literature even at the end of the 20th century (see Boychuk).

In the same year, another publication appeared, i.e. "Return of Demiurges" or, more precisely, "Concise Ukrainian Encyclopaedia of Modern Literature" with a chrestomathic addendum edited by Volodymyr Yeshkilev and Yuri Andrukhovych. Its authors declared the intention to sum up the 20th century Ukrainian modernism legacy (see Yeshkilev, Andrukhovych). Chronologically, the publication contains works written and read by contemporaries, that is, mostly during the last quarter of the century. However, by its name and methodological principle (at least in the form that Volodymyr Yeshkilev presented and consistently applied) it rather rounds up the epoch of modernism than offers a postmodern perspective. The construction of hierarchies, citation of Verlaine and references to Nietzsche with his cult of will and superman, rejection of the past and refocusing to the present, all this makes in-publication authors be self-proclaimed "demiurges". Aestheticism and voluntarism opposed postmodern irony, and demiurgic traits were manifested not only through the ability to create, but also through the ability to dominate and control. Even if the authors play a literary game, it is a single set, in which winners and losers are determined in advance. The reward in this game is the language itself, including the right to use it for personal needs, that is, to create individual artistic worlds.

Game without rules: author as a player. In the process of compiling anthologies Ukrainian postmodernism is manifested in a rather situational than programmatic manner. General socio-political conditions and the course of everyday life shaped a postmodern attitude perhaps more powerfully than the theoretical ideas borrowed from Western intellectuals. The destruction of ideological and aesthetic hierarchies, rapid depreciation of former values, fragmentarity of the new knowledge of the world and of oneself and unpredictability of not only their own future, but also their own past, questioned the objectivity of any selection and editing criteria. 
A number of anthologies published in the 1990s present the as-is material without any value judgements. The work of an editor becomes the work of an archivist who intends to collect and save everything written during the time when it is impossible to predict what and when it will be needed in future. The editors are guided by a classical genre model which should hierarchize and canonize the selected material. Their inability to select they recognize as a shameful but inevitable disadvantage. In the preface to anthology "Young Wine" (1994) Serhii Rudenko asks the readers for an excuse for the incompleteness of the literature presentation and expresses his hope that a more comprehensive publication will appear over time (Rozumnyi and Rudenko, 6). In the preface to the anthology "Noun" (1997), Andrii Kokotyukha contemplates a barrage of accusations for his subjectivism and convinces that the editors tried to adhere to objective selection criteria, but the literary situation itself does not allow for their identification (Kokotiukha, Rozumnyi 6).

Literature, which for a long time resisted totalitarian restrictions, tries various content and formal experiments. A variable range of voices and practices testifies not so much to the results as open opportunities. The self-awareness of a new literary community starts through the negation. It is reflected even in the publication titles, for instance "Anthology of Alternative Ukrainian Poetry on the Change of Epochs: the 2nd half of the 80's and the beginning of the 90's" (see Donii, Pozayak) or "Bilingual Anthology of Young Ukrainian Poetry: Contra Meanings" (see Donii, Bondar) both published in 2001. Editors are aware of the incompleteness and often the unpredictability of the subject being represented, i.e. modern Ukrainian literature. Ivan Andrusiak, an editor of anthology "The Nineties: Poetic Anthology of a New Generation" (1994), calls it uneven and incomplete emphasizing that the issue presents what is happening at the moment but not what happened in the past (Andrusiak, 21). Similar projects are not retrospective; on the contrary, they are future-targeted, very close future that has begun just recently. Again, they do not try to reconstruct a specific community; they create it as an accidental and temporary one, rather a gaming community than a memory community.

Publications containing works selected per authors rather than specific pieces of writing should be mentioned individually: a compiler formulates any cross-cutting topic or determines a problem and invites the authors to ponder over it. By applying such collaborative efforts a literary phenomenon is created which did not exist until the moment of representation. Since it does not pretend to take its place in the canon but is determined by the context and a specific reader's request, the subject itself changes: now it does pertain to the presentation of national literature, historical periods or specific genres, but to such optional things as, for example, football (see Zhadan 2011, 2012) or dreams (see Malkovych 2010). Such literary games, however, are not reduced to fun: in an unexpected way (not through a search of the better one but the other one) they uncover contradictions of different cultural phenomena, in the above cases - mass literature and writing practice as well as the mimetic nature of literature. 
Private collection: author as an individual. At the beginning of the 21st century, after experiencing denial, experimentation and marginalization, the anthological form returns back to renewing its original function, i.e. sampling the best of what was written and read. An editor takes the role of a professional reader. He shares his reading experience hoping to give it the status of a shared cultural space, where actual meanings and values are formed. The necessity to establish a new representation of modern literature as a self-articulation of the cultural community stimulates the above process.

The model of authorship as a subjective self-expression was discussed for the first time in an anthology of "the new Ukrainian poetry" under the title "Eighties" (generation of eighties) edited by Ihor Rymaruk and published in Edmonton in 1990 (see Rymaruk). It offers an alternative not only to the Soviet canon, but also to the anti-Soviet ideologically-oriented literature treated as a "service to society". The essayist and poet, Mykola Riabchuk, begins his preface with Natalka Bilotserkivets's poem "We will die not in Paris..." which problematizes the status of the author in the Ukrainian context: Paris symbolizes "not geography and politics, but culture, a system of convention symbols", "a capital of arts" (Rymaruk, xi). Considering "the aesthetic position" as "desirable but unacceptable luxury" (Rymaruk, xiv) Riabchuk, however, recognizes it as a norm and a dream of the "new" Ukrainian literature seeking its own identity. The very term "identity" appears in a text in English as borrowed, but not yet fully internalized by the Ukrainian literary vocabulary.

Another project which balances between the social and aesthetic understanding of the notion of "a writer" is the anthology "Flowers in a Dark Room" by Volodymyr Danylenko which presents "the brightest samples of the Ukrainian short story over the past fifteen years» (see Danylenko 1997b). Like the previous one, this edition offers a new version of contemporary Ukrainian literary canon as an alternative to socialist realism. It is noteworthy that the compiler attributes the emergence of a new style not to a new (post-Soviet) era, but to a new type of author, which has been formed back in the 1960s. However, he focuses mainly on installing a common theme and the idea of a new generation, and defines "the critique of society" as "the most significant leitmotif" of the entire generation (Danylenko 1997b: 10). And yet "Flowers in a Dark Room" and following publications in this book series gradually shift the attention from ideology to poetics (see Danylenko 1997a; 1997c).

Rymaruk and Danylenko define literature as represented by their anthological editions as "new", which means that they avoid more definite and unifying features. The same adjective is also used in the subtitle of the anthology "From Three Worlds" edited by Ed Hogan (see Hogan). Solomea Pavlychko in her preface to this bilingual collection articulates "two things" that are common to writers of different generations, social background and poetical manner: "All had stories to tell and, for the first time, all had the chance to compete for an audience" (Hogan 12). Among the most important issues of contemporary literature, she highlights the question of 
the status and role of the writer: "What was "my" role as a Ukrainian writer to be in a new society?" (Hogan, 13)

The selection of such literary collections at the beginning of the 21st century, unlike totalitarian or even anti-totalitarian projects of the 20th century, is performed without considering external ideological demands. Instead, the principle of a personal fancy becomes the basic one. An editor forms a selection stipulating his own offer and emphasizing its subjective nature. It is not a mere coincidence that Vasyl Gabor calls his anthology of selected Ukrainian prose and essays of the end of the 20th century "Private Collection" (see Gabor 2002). The principle of individualization acquires here the ultimate embodiment: the main factor of selection is the individual taste which manifests itself through emotional influence: "to this book were selected works that I love" (Gabor 2002: 7). Literature thus appears as a reading of individual authors in accordance with individual reader's tastes. After publishing a solid volume containing the works of 40 authors in 2002, the editor takes on new projects transforming the original idea of the publication into the idea of a series. Following anthologies show how the reader's interest develops in directions that have continually been beyond the scope of attention. Gender sensitivity leads to the creation of the anthology of Ukrainian "female" prose and essays of the second half of the 20th - beginning of the 21st century under the title "Unknown" (see Gabor 2005), searches for the urban tradition result in the anthology of the youngest Lviv literary bohème of the 30s of the 20th century "Twelve" (see Gabor 2006), etc. The editor views his publications as a collection of observations and finds, points to the passionate and intuitive nature of his selection.

Anthologies of the above type view the literature not from the objective intellectual distance, but from the perspective of private relations. It is not just a matter of personal acquaintance with the majority of writers whose works are included into the publication. The idea of the 20th century Ukrainian scope is formed as a result of private reading, personal acquaintance with works, which for one reason or another were removed from the canon, censored or squeezed in frameworks of ideological interpretations. They return "in real time" mode following personal re-reading, and the subjectivity of collections turns from the drawback into the virtue. No wonder that in almost all anthologies representing Ukrainian literature of the last hundred years there appear some names still unknown to the readership.

An example of such an open project and flexible canon-formation is, in particular, "Anthology of Ukrainian Literature of the Twentieth Century" edited by Ivan Malkovych. If Vasyl Gabor continues his project by publishing new anthologies, Malkovych re-publishes the same anthology expanding its content. Its first edition appeared in 2016, the second one subtitled "From Tychyna to Zhadan", in 2017. Moreover, the author applies an unconventional manoeuvre. Below the content presenting the works per authors' collections he lists authors whose works he wanted, but could not include in the anthology remarking: "The authors whose poems 
were selected for this Anthology, but they have still remained in the manuscript as printers limited the book to 2 thousand pages" (Malkovych 2017: 14-15). With such an unprecedented gesture, the author points out more than a hundred names that could be included in future literary collections. Therefore, literature is viewed as a hierarchical, but at the same time, a versatile system capable of generating new and original representative collections.

Social gesture: author as a public intellectual. The remaining two models, emphasizing the projective and dialogic nature of anthologies, become a prerequisite for the emergence of another type of publication which serves as a kind of social gesture highlighting topical problems and initiates, if not the discussion, at least their articulation. In Ukrainian literature they appeared during the last decade, e.g. "Solomon's Red Star" (2012) edited by Les Beley (see Beley) or "Mum on Skype" (2013) edited by Marjana Savka and Katya Brunner (see Savka, Brunner). The former is an attempt to textualise Ukraine as a space divided into separate regions, a rethinking of the Soviet administrative division from the 21st century perspective. In the latter, the problem of labour migration is discussed since it leads to the separation of families and eventually turns into a general social problem rooted in isolated instances.

Such publications are based on the author authority, not the text. The response to the invitation of an editor who initiates such project means an agreement for the own presence and involvement in the discussion of socially important issues. Sometimes such form of a collective narrative becomes the only one possible, especially when personal testimonies are fragmentary and partial. An example of such anthologies is numerous publications appeared in Ukraine in 2014 immediately after the Revolution of Dignity. Some authors record in their works the depth of emotional injury upon experiencing not only the rise but also the trauma received due to the collectively experienced brutal force. In particular, this is manifested in the inability of a language to convey the essence of ongoing events. Then, anthologies become a culture forming mechanism enabling the emergence of discourse - as "EuroMaidan: Chronicle of Feelings", "EuroMaidan: Lyrical Chronicle" and "EuroMaidan: Chronicle in Short Stories" (see Karpiuk 2014a; 2014b; 2014c).

The lack of artistic speech and its inability to influence the reality during the Maidan generate anthological projects where the margin between artistic and non-artistic expression is uncertain. Posts from social networks, opinions and other forms of narrative marking an author as the subject ready to testify, go hand in hand in the publications - as in the "Chronicle of Witnesses: Nine Months of Ukrainian Resistance" (see Teren). Given that not only the previous idea of literature collapses, but also the general vision of a human (due to unlawful violence), literature has to be invented again by restoring the ability of a language to denote the reality, to establish links between words and things. Not only the author's but also the reader's community designed via such publications is determined primarily by common values and meanings. "Majdan! Ukraine, Europa" (2014) in German (see 
Dathe, Rostek) contains literary and journalistic essays (genre marked by the highest degree of set author's presence) of Ukrainian and non-Ukrainian authors; poetic anthology "Wschód - Zachód: Wiersze z Ukrainy i dla Ukrainy" (2014) in Polish (see Kamińska) features the poetry of Ukrainian and Polish authors; poetic anthology "Letters from Ukraine" (2016) in Polish and English (see Semenchuk) combines works originally written by Ukrainian and Russian speaking authors from Ukraine, and "Words for War: New Poems from Ukraine" in English (see Maksymchuk, Rosochinsky) also contains works by Ukrainian authors from outside Ukraine and a small dictionary related to the war experience.

The ability of literature to testify, that is, to denote without employing finite definitions in difficult situations require a detailed and in-depth discussion and is now the basis for new anthology projects aimed at debating acute social problems. One of them is "Against Violence", a collection published in 2017 (see Denysenko). Omitting the first three letters from each word written in the Ukrainian title, shows a new title, i.e. "Pro(ty) Nas(ylstva)" ("About us"). The collection contains violence-themed works by 10 authors. However, they do not stop but rather inspire a conversation: each of them is commented by a professional psychologist, the entire selection is commented by lawyers and proved with texts of legal documents. The publication warns against direct use for solving specific legal problems, but through the power of individual voices and collective sounding it begins a conversation, i.e, it promotes the emergence of a new discourse.

In general, anthology as a genre originated in the 19th century within the context of the national literary traditions formation and establishment of canons remained relevant in Ukrainian literature over the next two centuries, but varied depending on cultural circumstances, readers' queries and a general concept of the literature. Keeping memory in its original role, each new type of anthology project neither denies nor pushes out, but rather complements the classical model. Various practices, editorial strategies and publishing approaches reflect and simultaneously design various types of literary mythology in the centre of which rests the figure of an author as a creator of the textual world.

\section{REFERENCES}

Adelheim Yevhen, ed. Ukrainska radianska poezia: antolohia. Kyiv: Derzhavne vydavnyctvo khudozhnioi literatury, 1948.

Andrusiak Ivan, ed. Deviadesiatnyky: poetychna antolohia novoho pokolinnia. Pereval, 1994. № 1.

Antolohia ruska: zbirnyk naiznamenytshykh tooriv ruskykh poetiv. Lviv: Vydannia tovarystva akademichnoho "Druzhnii lykhviar", 1881.

Assmann Aleida, Gomille Monika, Rippl Gabriele, hrsg. Sammler - Bibliophile - Exzentriker. Tuebingen: Narr Verlag, 1998. 


\section{OLENA HALETA, A WRITER OR A CREATOR OF THE TEXTUAL WORLD..}

Atamaniuk Vasyl, Pluzhnyk Yevhen, Yakubovskyi Feliks, eds. Antolohia ukrainskoi poezii: v 3-kh tomakh. Kyiv: Knyhospilka, 1930-1931.

Baudrillard Jean. The System of Objects. London: Verso, 1996.

Belei Les, ed. Solomonova Chervona Zirka. Kyiv: Tempora, 2012.

Benedict, Barbara M. Making the Modern Reader: Cultural Mediation in Early Modern Literary Anthologies. Princeton: Princeton UP, 1996.

Benjamin, Walter. "Eduard Fuchs: Collector and Historian". The Essential Frankfurt School Reader. Ed. Arato A., Gebhardt E., New York: Continuum, 1982. P. 225-253.

Bondar Andrii, Donii Tetiana, eds. Dvomovna antolohia molodoi ukrainskoi poezii: protyznachennia. Lviv: Kalvaria, 2001.

Boychuk Bohdan, Rubchak Bohdan, eds. Koordynaty: antolohia suchasnoi ukrainskoi poezii na Zakhodi: u 2 tomakh. Munchen: Suchasnist, 1969.

Boychuk Bohdan, ed. Poza tradycii: antolohia ukrainskoi modernoi poezii v diaspori. Kyiv, Toronto, Edmonton, Ottawa: CIUS, 1998.

Danylenko Volodymyr, ed. Vecheria na dvanadtsiat personzhytomyrska prozova shkola. Kyiv: Geneza, 1997a.

Danylenko Volodymyr, ed. Kvity v temnii kimnati: suchasna ukrainska novela. Kyiv: Geneza, 1997b.

Danylenko Volodymyr, ed. Opudalo: ukrainska prozova satyra, humor, ironia 80-90-ch rokiv dvadciatoho stolittia. Kyiv: Geneza, 1997c.

Dathe Claudia, Rostek Andreas, hrsg. Majdan! Ukraine, Europa. Berlin: edition.fotoTAPETA_Flugschrift, 2014.

Clifford James. Kłopoty z kultura: dwudziestowieczna etnografia, literatura i sztuka. Warszawa: KR, 2000.

Denysenko Larysa, ed. Proty nasylstva. Kyiv: VAITE, 2016.

Di Leo, Jeffrey R. On Anthologies: Politics and Pedagogy. Lincoln: University of Nebraska Press, 2004.

Domanytskyi Vasyl, Yefremov Serhii, eds. Vik (1799 - 1898): volume 1, 2. Kyiv: Drukarnia S. V. Kulizhenko, 1900; Kyiv: Drukarnia P. Barskoho, 1902.

Donii Tetiana, Pozaiak Yurko, eds. Antolohia alternatyonoi ukrainskoi poezii zminy epokh: druha polovyna 80-kh-pochatok 90-kh rokiv. Kharkiv: Maidan, 2001.

Elsner John, Cardinal Roger, eds. The Cultures of Collecting. London: Reaction Books, 1994.

Essmann, Helga. Übersetzungsanthologien: eine Typologie und eine Untersuchung am Beispiel der amerikanischen Versdichtung in deutschsprachigen Anthologien, 1920-1960. Frankfurt am Main, Berlin, Bern, New York, Paris, Wien: Peter Lang, 1992.

Ferry, Anne. Tradition and the Individual Poem: an Inquiry into Anthologies. Stanford: Stanford UP, 2001.

Franko Ivan, ed. Akordy: antolohia ukrainskoi liryky vid smerty Shevchenka. Lviv: Nakladom Ukrainsko-Ruskoi Vydavnychoi Spilky, 1903.

Gabor Vasyl, ed. Dvanadciatka. Naimolodsha lvivska literaturna bohema 30-ch rokiv XX stolittia: antolohia urbanistychnoi prozy. Lviv: Piramida, 2006.

Gabor, Vasyl, ed. Neznaioma: antolohia ukrainskoi "zhinochoi" prozy ta eseistyky druhoi pol. XX - poch. XXI stolittia. Lviv: Piramida, 2005.

Gabor Vasyl, ed. Pryvatna kolekcia: vybrana ukrainska proza ta eseistyka kincia XX stolittia. Lviv: Piramida, 2002.

Genette, Gérard. "Palimpsesty". Teoria literatury i metodologia badań literackich. Red. Ulicka D., Warszawa: Uniwersytet Warszawski, Wydawnictwo Dydaktyczne Wydziału Polonistyki, 1999. S. 107-154. 
Germano, William P. Getting It Published: a Guide for Scholars and Anyone Else Serious about Serious Books. Chicago: University of Chicago Press, 2008.

Goethe, Johann Wolfgang von. "Kolekcjoner i inni". Wybór pism estetycznych. Namowicz T., red. Warszawa: Państwowe Wydawnictwo Naukowe, 1981. S. 181-204.

Grijp, Paul van der. Passion and Profit: toward an Anthropology of Collecting. Münster, Berlin, Hamburg, London, Wien: Lit, 2006.

Groys, Boris. “Logik der Sammlung”. Logik der Sammlung: am Ende des musealen Zeitalters. München, Wien: Carl Habser Verlag, 1997a. S. 25-45.

Groys, Boris. "Sammeln und gesammeln warden". Logik der Sammlung: am Ende des musealen Zeitalters. München, Wien: Carl Habser Verlag, 1997b. S. 46-62.

Haleta, Olena. Vid antolohii do ontolohii: antolohia iak sposib reprezentacii ukrainskoi literatury kincia XIX pochatku XXI stolittia. Kyiv: Smoloskyp, 2015.

Hogan Ed, ed. From Three Worlds: New Ukrainian Writing. Boston: Zephyr Press, 1996.

Hrebinka Yevhen, ed. Lastivka: sochinenia na malorossiiskom yazykie. Saint Petersburg: Izdatelstvo knigoprodavca Vasilia Poliakova, 1841.

Iampolski, Mikhail. Nabliudatel: ocherki istorii videnia. Moscow: Ad Marginem, 2000.

Kamińska Aneta, wybór i przekł. Wschód - Zachód: wiersze z Ukrainy i dla Ukrainy. Bydgoszcz: Pobocza Peryferii, Miejskie Centrum Kultury, 2014.

Karpiuk Vasyl, ed. Euromaidan: khronika v novelakh. Brusturiv: Dyskursus, 2014a.

Karpiuk Vasyl, ed. Euromaidan: khronika vidchuttiv. Brusturiv: Dyskursus, 2014b.

Karpiuk Vasyl, ed. Euromaidan: lirychna khronika. Brusturiv: Dyskursus, 2014c.

Kokotiukha Andrii, Rozumnyi Maksym, eds. Imennyk: antolohiia devianostykh. Kyiv: Smoloskyp, 1997.

Korte Barbara. "Flowers for the Picking: Anthologies of Poetry in (British) Literary and Cultural Studies". Anthologies of British Poetry: Critical Perspectives from Literary and Cultural Studies. Ed. Korte R., Schneider R., Lethbridge S., Amsterdam, Atlanta: Rodopi, 2000. P. 1-32.

Kovalenko, Oleksa, ed. Ukrainska Muza: poetychna antolohia od pochatku do nashykh dniv. Kyiv: Vik, 1908. Is. $1-12$.

Kravtsiv Bohdan, ed. Obirvani struny: antolohia poezii poliahlykh, zamuchenykh, rozstrilianykh i zaslanykh 1920-1945. New York: Naukove tovarystvo im. T. Shevchenka v Kanadi, 1955.

Łapiński Zdzisław, Tomasik Wojciech, red. Stownik realizmu socjalistycznego. Kraków: Universitas, 2004.

Lavrinenko Yuri, ed. Rozstriliane Vidrodzhennia: antolohia 1917-1933: poezia - proza - drama - esei. Paris: Instytut Literacki, 1959.

Lévi-Strauss, Claude. The Savage Mind. London: Weidenfeld and Nicolson, 1966.

Maksymchuk Oksana, Rosochinsky Max, eds. Words for War: New Poems from Ukraine. Boston: Academic Studies Press, 2017.

Malkovych Ivan, ed. Antolohia ukrainskoi literatury XX stolittia: vid Tychyny do Zhadana. Kyiv: A-ba-ba-ha-la-ma-ha, 2017.

Malkovych Taras, ed. Snovydy: sny ukrainskykh pysmennykiv. Kyiv: A-ba-ba-ha-la-ma-ha, 2010.

Muensterberger, Werner. Collecting: an Unruly Passion. Princeton, New Jersey: Princeton University Press, 1994. 
Olsson, Anders. Managing Diversity: the Anthologization of "American Literature". Acta Universitatis Upsaliensis. Studia Anglistica Upsaliensia 111. Uppsala, 2000.

Pavlyshyn, Marko. "Literary history as provocation of national identity, national identity as provocation of literary history: The case of Ukraine". Thesis Eleven. 136(i), 2016. P. 74-89.

Pearce, Susan. On Collecting: an Investigation into Collecting in the European Tradition. London, New York: Routledge, 1995.

Pomian, Krzysztof. "Kolekcjonerstwo i filozofia. Narodziny nowożytnego museum”. Drogi kultury europejskiej: Trzy studia. Warszawa: PAN, Instytut Filozofii i Socjologii, 1996a.

Pomian, Krzysztof. Zbieracze i osobliwości: Paryż - Wenecja, XVI-XVIII wiek. Warszawa: Państwowy Instytut Wydawniczy, 1996b.

Rozumnyi Maksym, Rudenko Serhii, eds. Molode vyno: antolohia poezii. Kyiv: Smoloskyp, 1994.

Rylskyi Maksym, Nahnybida Mykola, eds. Antolohia ukrainskoi poezii: v 4-kh tomakh. Kyiv: Derzhavne vydavnyctvo khudozhnioi literatury, 1957.

Rymaruk Ihor, ed. Visimdesiatnyky: antolohia novoi ukrainskoi poezii. Edmonton: Vydavnytstvo CIUS, 1990.

Sánchez, Yvette. Coleccionismo y literatura. Madrid: Cátedra, 1999.

Savka Mariana, Brunner Kati, eds. Mama po Skype. Lviv: Vydavnyctvo Staroho Leva, 2013.

Schellenberg, Renate. "The Self and Other Things: Goethe the Collector". Publications of the English Goethe Society. 3 (2012). P. 166-177.

Schmidt, Henrike. Fiktive Anthologien in der bulgarischen Literatur der Post/Moderne: Kreation des Kanons als Kunst: Beschreibung des Vorhabens [manuskript]. Berlin, 2014.

Semenchuk Hryhory, ed. Letters from Ukraine: Poetry Anthology. Ternopil: Kolo, 2016.

Shklovsky Viktor. "Zhurnal kak literaturnaia forma”. Gamburgskii schet. Leningrad: Izdatelstvo pisateliej v Leningrade, 1928. P. 112-117.

Stewart, Susan. On Longing: Narratives of the Miniature, the Gigantic, the Souvenir, the Collection. Baltimore: The Johns Hopkins UP, 1984.

Teren Tetiana, ed. Litopys samovydciv: deviat misiaciv ukrainskoho sprotyvu. Kyiv: Komora, 2014.

Tynyanov, Yury. “Literaturnyi fakt”. Poetika. Istoriia literatury. Kino. Moscow: Nauka, 1977b. P. 255-270.

Tynyanov, Yury. "Zhurnal, kritik I chitatel". Poetika. Istoriia literatury. Kino. Moscow: Nauka, 1977a. P. 147-149.

Vynnychuk Yuri, ed. Rozipiata muza: antolohia ukrainskykh poetiv, iaki zahynuly nasylnyckoiu smertiu: u 2-kh tomakh. Lviv: Piramida, 2011.

Weiskopf, Mikhail. Pisatel Stalin. Moscow: NLO, 2001.

Yakubskyi Borys, ed. Halytska ta bukovynska poezia XX viku. Kharkiv: Knyhospilka, 1930.

Yeshkilev Volodymyr, Andrukhovych Yuri, eds. Povernennia demiurhiv / Pleroma 3'98. Mala ukrainska encyklopedia aktualnoi literatury. Ivano-Frankivsk: Lilea-NV, 1998.

Zhadan Serhii, ed. Pysmennyky pro futbol: literaturna zbirna Ukrainy. Kharkiv: KSD, 2011.

Zhadan Serhii, ed. Totalnyi futbol. Kyiv: Hrani-T, 2012. 